\title{
Pemberian Bokashi Sekam Padi Terhadap Pertumbuhan Dan Hasil Sawi Ladang (Nasturtium montanum Wall.)
}

\author{
Nurhadiah \\ Fakultas Pertanian Universitas Kapuas Sintang \\ email:dnurhadiah@gmail.com
}

\begin{abstract}
Abstrak: Sawi ladang adalah sawi yang ditanam oleh petani padi lahan kering pada saat musim berladang yang hanya ditanam untuk konsumsi sehari-hari. Untuk mendapatkan sawi ladang diluar musim berladang maka perlu pengelolaannya yang intensif, mengingat sebagian besar lahan di Kabupaten Sintang kurang kandungan bahan organiknya. Salah satu pupuk organik yang dapat digunakan yaitu bokashi sekam padi. Adapun tujuan penelitian ini yaitu untuk mengetahui pengaruh bokashi sekam padi terhadap pertumbuhan dan hasil tanaman sawi ladang pada tanah PMK dan mengetahui dosis bokashi sekam padi yang memberikan pengaruh pertumbuhan dan hasil tanaman sawi ladang yang terbaik pada tanah PMK. Penelitian ini menggunakan metode eksperimen lapangan dengan menggunakan Rancangan Acak Kelompok (RAK). Perlakuan yang digunakan adalah bokashi sekam padi yang terdiri dari 5 taraf perlakuan yang diulang sebanyak 5 kali. Taraf perlakuan yang dimaksud yaitu: $\mathrm{B}_{0}=\operatorname{tanpa}$ pemberian bokashi sekam padi (kontrol), $\mathrm{B}_{1}=$ pemberian bokashi sekam padi sebanyak $1 \mathrm{~kg}$ per petak, $\mathrm{B}_{2}=$ pemberian bokashi sekam padi sebanyak $2 \mathrm{~kg}$ per petak, $\mathrm{B}_{3}=$ pemberian bokashi sekam padi sebanyak $3 \mathrm{~kg}$ per petak, dan $\mathrm{B}_{4}=$ pemberian bokashi sekam padi sebanyak $1 \mathrm{~kg}$ per petak. Peubah yang diamati adalah tinggi tanaman per tanaman $(\mathrm{cm})$, jumlah daun per tanaman (helai) dan berat segar tanaman (gram). Data dianalisis dengan Analisis Sidik Ragam dan Uji Lanjut Beda Nyata Jujur (BNJ) pada taraf 0,05 dan 0,01. Hasil penelitian diketahui bahwa bokashi sekam padi berpengaruh sangat nyata terhadap pertumbuhan dan hasil tanaman sawi ladang pada tanah PMK. Dosis $3 \mathrm{~kg}$ bokashi sekam padi per petak memberikan pertumbuhan dan hasil yang terbaik tanaman sawi ladang pada tanah PMK dengan tinggi tanaman 15,04 cm, jumlah daun 5,50 helai dan berat segar tanaman 50 gram.
\end{abstract}

Kata Kunci: Bokashi Sekam Padi, Sawi Ladang, Pertumbuhan, Hasil.

\section{PENDAHULUAN}

Tanaman sawi ladang

(Nasturtium montanum Wall) sangat banyak memberikan manfaat bagi kesehatan seperti untuk menghilangkan rasa gatal di tenggorokan pada penderita batuk. Penyembuh penyakit kepala, bahan pembersih darah, memperbaiki fungsi ginjal, serta memperbaiki dan memperlancar pencernaan. Adapun kandungan yang terdapat pada sawi 
Pemberian Bokashi Sekam Padi Terhadap Pertumbuhan Dan

Hasil Sawi Ladang (Nasturtium montanum Wall.)

adalah protein, lemak, karbohidrat, $\mathrm{Ca}, \mathrm{P}, \mathrm{Fe}$, Vitamin A, Vitamin B, dan Vitamin C (Cahyono, 2015:1).

Sawi ladang adalah sawi yang ditanam oleh petani padi lahan kering pada saat musim berladang yang hanya ditanam untuk konsumsi sehari-hari. Untuk mendapatkan sawi ladang diluar musim berladang maka perlu pengelolaannya yang intensif, mengingat sebagian besar lahan di Kabupaten Sintang kurang kandungan bahan organiknya. Bahan organik dapat memperbaiki sifat fisik tanah, biologi dan kimia tanah. Menurut Sudiarto dan Gusmaini (2004:40) pupuk organik berperan penting dalam memperkaya bahan organik tanah sehingga aktivitas mikroorganisme tanah meningkat, memperbaiki struktur tanah sehingga tidak mudah rusak karena erosi percikan. Salah satu pupuk organik yang dapat digunakan yaitu bokashi sekam padi. Bokashi sekam padi adalah pupuk organik dengan bahan utama sekam padi, dimana sekam padi ini kurang dimanfaatkan oleh petani di Kabupaten Sintang, sehingga dapat diperoleh dengan mudah terutama di musim panen.
Hasil analisis kimia bokashi sekam padi diketahui $\mathrm{pH}$ 6,48 (status agak masam) C-organik 85\% (status sangat tinggi), Nitrogen $0,85 \%$ (status sangat tinggi), $\mathrm{C} / \mathrm{N} \quad 99,59$ (status sangat tinggi), $\mathrm{P}_{2} \mathrm{O}_{5}$ 0,25 ppm (status sangat rendah) dan $\mathrm{K}_{2} \mathrm{O} \quad 0,28$ ppm (status sangat rendah) (Kesumaningwati, 2014). Adanya aktivitas mikroorganisme tanah, bokashi sekam padi yang diberikan ke dalam tanah dapat mengalami dekomposisi lanjut sehingga status hara sangat rendah dapat meningkat dan tersedia bagi pertumbuhan tanaman. Untuk itu perlu dilakukan penelitian tentang pemberian bokashi sekam padi terhadap pertumbuhan dan hasil sawi ladang (Nasturtium montanum Wall.) dengan tujuan untuk mengetahui pengaruh bokashi sekam padi terhadap pertumbuhan dan hasil tanaman sawi ladang pada tanah PMK dan mengetahui dosis bokashi sekam padi yang memberikan pengaruh pertumbuhan dan hasil tanaman sawi ladang yang terbaik pada tanah PMK. 


\section{METODOLOGI PENELITIAN}

Penelitian ini dilakukan dengan menggunakan metode eksperimen lapangan, menggunakan Rancangan Acak Kelompok (RAK). Perlakuan yang digunakan adalah bokashi sekam padi yang terdiri dari 5 taraf perlakuan yang diulang sebanyak 5 kali. Taraf perlakuan yang dimaksud yaitu: $\mathrm{B}_{0}=$ tanpa pemberian bokashi sekam padi (kontrol), $\quad \mathrm{B}_{1}=$ pemberian bokashi sekam padi sebanyak $1 \mathrm{~kg}$ per petak, $\mathrm{B}_{2}=$ pemberian bokashi sekam padi sebanyak $2 \mathrm{~kg}$ per petak, $\mathrm{B}_{3}=$ pemberian bokashi sekam padi sebanyak $3 \mathrm{~kg}$ per petak, dan $\mathrm{B}_{4}=$ pemberian bokashi sekam padi sebanyak $1 \mathrm{~kg}$ per petak. Jumlah tanaman percobaan sebanyak 400 tanaman (16 tanaman setiap petak $\mathrm{x}$ 5 taraf perlakuan x 5 ulangan). Jumlah tanaman pengamatan sebanyak 100 tanaman (4 tanaman setiap petak x 5 taraf perlakuan x 5 ulangan). Alat-alat yang digunakan dalam penelitian ini yaitu parang, cangkul, gembor, meteran, timbangan, kamera, kantong plastik, alat tulis menulis dan komputer.
Bahan penelitian yang di gunakan adalah Benih sawi ladang, sekam padi sebanyak $100 \mathrm{~kg}$, pupuk kandang kotoran ayam sebanyak 10 kg, EM 4 sebanyak $50 \mathrm{ml}$ dan gula pasir 4 sendok makan. Peubah yang diamati adalah tinggi tanaman per tanaman (cm), jumlah daun per tanaman (helai) dan berat segar tanaman (gram). Data dianalisis dengan Analisis Sidik Ragam dan Uji Lanjut Beda Nyata Jujur (BNJ) pada taraf 0,05 dan 0,01 . Penelitian dilaksanakan di Kelurahan Akcaya Kecamatan Sintang Kabupaten Sintang. Penelitian ini dimulai bulan Maret sampai Mei 2019.

\section{HASIL DAN PEMBAHASAN}

Tinggi Tanaman

Tinggi tanaman diukur menggunakan meteran mulai dari pangkal batang sampai daun yang terpanjang. Pengukuran dilakukan terhadap semua tanaman pengamatan sehari sebelum panen. Data hasil pengukuran tinggi tanaman dianalisis menggunakan analisis sidik ragam, yang hasilnya dapat dilihat pada Tabel 1. 
Pemberian Bokashi Sekam Padi Terhadap Pertumbuhan Dan Hasil Sawi Ladang (Nasturtium montanum Wall.)

Tabel 1. Hasil Analisis Sidik Ragam (ANSIRA) Pemberian Bokashi Sekam Padi terhadap Tinggi Tanaman Sawi Ladang

\begin{tabular}{|c|c|c|c|c|c|c|}
\hline \multirow{2}{*}{ SK } & \multirow{2}{*}{ DB } & \multirow{2}{*}{ JK } & \multirow{2}{*}{ KT } & \multirow{2}{*}{$\begin{array}{l}\text { F } \\
\text { hitung }\end{array}$} & \multicolumn{2}{|c|}{ F tabel } \\
\hline & & & & & 0,05 & 0,01 \\
\hline Ulangan & 4 & 1,77 & 0,44 & 0,33 tn & 3,01 & 4,77 \\
\hline Perlakuan & 4 & 63,81 & 15,95 & $11,76 * *$ & 3,01 & 4,77 \\
\hline Galat & 16 & 21,70 & 1,36 & & & \\
\hline Total & 24 & 87,28 & & $\mathbf{k k}=$ & $9,01 \%$ & \\
\hline
\end{tabular}

Sumber: Hasil analisis data, 2019.

Keterangan:

tn = tidak berpengaruh pada taraf kepercayaan $95 \%$

** = berpengaruh nyata pada taraf kepercayaan $99 \%$

Hasil analisis sidik ragam

(Tabel 1) menunjukkan bahwa bokashi sekam padi berpengaruh nyata pada taraf kepercayaan $99 \%$ (berpengaruh sangat nyata) terhadap tinggi tanaman. Untuk mengetahui perbedaan pengaruh antar taraf bokashi sekam padi dilanjutkan dengan uji BNJ pada taraf nyata $5 \%$ dan $1 \%$ yang disajikan pada Tabel 2.

Tabel 2. Hasil Uji BNJ Bokashi Sekam Padi Terhadap Tinggi Tanaman (cm)

\begin{tabular}{llllll}
\hline Perlakuan & Rerata & Beda & & & \\
\hline $\mathbf{B}_{\mathbf{0}}$ & $11,26 \mathrm{a}$ & - & & & \\
$\mathbf{B}_{\mathbf{2}}$ & $11,56 \mathrm{a}$ & $0,30^{\mathrm{tn}}$ & - & & \\
$\mathbf{B}_{\mathbf{1}}$ & $12,11 \mathrm{a}$ & $0,86^{\mathrm{tn}}$ & $0,56^{\mathrm{tn}}$ & - & \\
$\mathbf{B}_{4}$ & $14,65 \mathrm{~b}$ & $3,39^{* *}$ & $3,09^{* *}$ & $2,54^{* *}$ & - \\
$\mathbf{B}_{\mathbf{3}}$ & $15,04 \mathrm{~b}$ & $3,79^{* *}$ & $3,49^{* *}$ & $2,93^{* *}$ & $0,40^{\text {tn }}$ \\
\hline BNJ 0,05 = & $\mathbf{0 , 9 4}$ & & BNJ 0,01 $=$ & $\mathbf{1 , 2 1}$ & \\
\hline
\end{tabular}

Sumber: Analisa data, 2019.

Keterangan:

tn = tidak beda nyata

$* *$ = beda nyata pada selang kepercayaan $99 \%$

Hasil uji BNJ pada Tabel 2 menunjukkan pemberian $3 \mathrm{~kg}$ bokashi sekam padi menghasilkan tinggi tanaman tertinggi meskipun tidak lebih tinggi dari tanaman yang diberi $4 \mathrm{~kg}$ bokashi sekam padi, selisih antara keduanya sebesar 0,40 cm per tanaman.

\section{Jumlah Daun}

Jumlah daun dihitung bersamaan dengan pengukuran tinggi tanaman. Penghitungan dilakukan pada daun yang telah membuka 
Pemberian Bokashi Sekam Padi Terhadap Pertumbuhan Dan Hasil Sawi Ladang (Nasturtium montanum Wall.)

sempurna, dilakukan pada seluruh tanaman pengamatan. Data hasil penghitungan jumlah daun tanaman dianalisis menggunakan analisis sidik ragam, yang hasilnya dapat dilihat pada Tabel 3 .

Tabel 3 Hasil Analisis Sidik Ragam (ANSIRA) Pemberian Bokashi Sekam Padi terhadap Jumlah Daun Tanaman Sawi Ladang

\begin{tabular}{|c|c|c|c|c|c|c|}
\hline \multirow{2}{*}{ SK } & \multirow{2}{*}{ DB } & \multirow{2}{*}{ JK } & \multirow{2}{*}{ KT } & \multirow{2}{*}{$\begin{array}{l}\text { F } \\
\text { hitung }\end{array}$} & \multicolumn{2}{|c|}{ F tabel } \\
\hline & & & & & $\mathbf{0 , 0 5}$ & $\mathbf{0 , 0 1}$ \\
\hline Ulangan & 4 & 0,08 & 0,02 & $0,11 \mathrm{tn}$ & 3,01 & 4,77 \\
\hline Perlakuan & 4 & 8,92 & 2,23 & $12,98 * *$ & 3,01 & 4,77 \\
\hline Galat & 16 & 2,75 & 0,17 & & & \\
\hline Total & 24 & 11,75 & & $\mathbf{k k}=$ & $9,11 \%$ & \\
\hline
\end{tabular}

Sumber: analisa data, 2019.

Keterangan:

tn = tidak berpengaruh pada taraf kepercayaan $95 \%$

** = berpengaruh nyata pada taraf kepercayaan $99 \%$

Hasil analisis sidik ragam mengetahui perbedaan pengaruh (Tabel 3) menunjukkan bahwa antar taraf bokashi sekam padi bokashi sekam padi berpengaruh dilanjutkan dengan uji BNJ pada nyata pada taraf kepercayaan $99 \%$ taraf nyata $5 \%$ dan $1 \%$ yang (berpengaruh sangat nyata) terhadap disajikan pada Tabel 4.

jumlah daun tanaman. Untuk

Tabel 4. Hasil Uji BNJ Bokashi Sekam Padi Terhadap Jumlah Daun (helai)

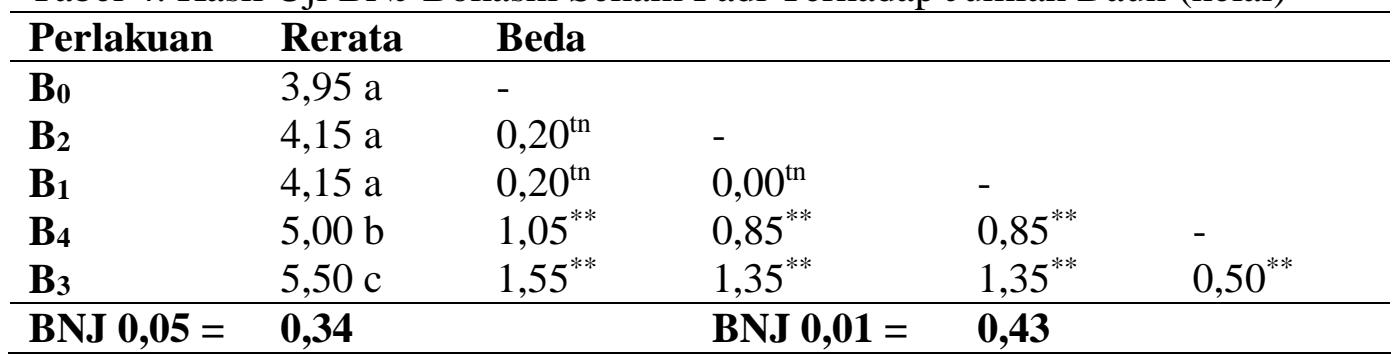

Sumber: analisa data, 2019.

Keterangan:

tn = tidak berbeda nyata pada selang kepercayaan $95 \%$

** = berbeda nyata pada selang kepercayaan $99 \%$

Hasil uji BNJ pada Tabel 4 menunjukkan pemberian $3 \mathrm{~kg}$ okashi sekam padi menghasilkan jumlah daun tanaman yang paling banyak. 
Pemberian Bokashi Sekam Padi Terhadap Pertumbuhan Dan Hasil Sawi Ladang (Nasturtium montanum Wall.)

\section{Berat Segar}

Berat segar tanaman diperoleh dengan cara menimbang tanaman bagian atas yang sudah diberihkan dari tanah dan akar. Data berat segar tanaman ini dianalisis menggunakan analisis sidik ragam, yang hasilnya dapat dilihat pada Tabel 5.

Tabel 5 Hasil Analisis Sidik Ragam (ANSIRA) Pemberian Bokashi Sekam Padi terhadap Berat Segar Tanaman Sawi Ladang

\begin{tabular}{lllllll}
\hline \multirow{2}{*}{ SK } & \multirow{2}{*}{ DB } & \multirow{2}{*}{ JK } & KT & F & F tabel & \\
\cline { 6 - 7 } & & & & hitung & $\mathbf{0 , 0 5}$ & $\mathbf{0 , 0 1}$ \\
Ulangan & 4 & 25,00 & 6,25 & 1,00 tn & 3,01 & 4,77 \\
Perlakuan & 4 & 2400,00 & 600,00 & $96,00 * *$ & 3,01 & 4,77 \\
Galat & 16 & 100,00 & 6,25 & & & \\
\hline Total & $\mathbf{2 4}$ & $\mathbf{2 5 2 5 , 0 0}$ & & KK $=$ & $\mathbf{7 , 8 1}$ & \\
\hline
\end{tabular}

Sumber: analisa data, 2019.

Keterangan:

tn = tidak berpengaruh pada taraf kepercayaan $95 \%$

** = berpengaruh nyata pada taraf kepercayaan $99 \%$

Hasil analisis sidik ragam

(Tabel 5) menunjukkan bahwa bokashi sekam padi berpengaruh nyata pada taraf kepercayaan $99 \%$ (berpengaruh sangat nyata) terhadap berat segar tanaman. Untuk mengetahui perbedaan pengaruh antar taraf bokashi sekam padi dilanjutkan dengan uji BNJ pada taraf nyata $5 \%$ dan $1 \%$ yang disajikan pada Tabel 6.

Tabel 6. Hasil Uji BNJ Bokashi Sekam Padi Terhadap Berat Segar Tanaman (gram)

\begin{tabular}{llllll}
\hline Perlakuan & Rerata & Beda & & & \\
\hline B $_{\mathbf{0}}$ & $25,00 \mathrm{a}$ & - & & & \\
$\mathbf{B}_{\mathbf{2}}$ & $25,00 \mathrm{a}$ & $0,00^{\mathrm{tn}}$ & - & & \\
B $_{\mathbf{1}}$ & $25,00 \mathrm{a}$ & $0,00^{\text {tn }}$ & $0,00^{\text {tn }}$ & - & \\
B $_{4}$ & $35,00 \mathrm{~b}$ & $10,00^{* *}$ & $10,00^{* *}$ & $10,00^{* *}$ & - \\
B $_{3}$ & $50,00 \mathrm{c}$ & $25,00^{* *}$ & $25,00^{* *}$ & $25,00^{* *}$ & $15,00^{* *}$ \\
\hline BNJ 0,05 $=$ & $\mathbf{2 , 0 3}$ & & BNJ 0,01 $=$ & $\mathbf{2 , 6 0}$ & \\
\hline
\end{tabular}

Sumber: analisa data, 2019.

Keterangan:

tn = tidak beda nyata selang kepercayaan $95 \%$

$* *$ = beda nyata pada selang kepercayaan $99 \%$ 
Hasil uji BNJ pada Tabel 6 memperlihatkan bahwa berat segar tertinggi dihasilkan dari tanaman yang diberi $3 \mathrm{~kg}$ bokashi sekam padi. Pada tanaman yang diberi $1 \mathrm{~kg}$ dan 2 $\mathrm{kg}$ tidak lebih berat dari tanaman yang tanpa diberi bokashi sekam padi.

Hasil penelitian menunjukan bahwa pemberian bokashi sekam padi berpengaruh sangat nyata terhadap pertumbuhan dan hasil sawi ladang pada tanah PMK. Penelitian serupa menggunakan bokashi sekam padi berpengaruh terhadap pertumbuhan dan hasil jagung manis (Nurhadiah, 2016:153), berpengaruh terhadap pertumbuhan dan hasil kangkung darat (Yulianingsih, 2018:382).

Pertumbuhan dapat diketahui dengan tinggi tanaman dan jumlah daun serta hasil dapat diketahui dengan berat segar tanaman. Hal ini karena pemberian bokashi sekam padi menyebabkan bahan organik tanah menjadi bertambah sehingga kondisi tanah menjadi lebih baik. Menurut Harjadi (1991:175) penambahan bahan organik akan meningkatkan kestabilan struktur, tekstur, daya olah, tata air dan udara tanah. Buckman dan Brady (1982;25) menjelaskan bahwa sifat fisika tanah berpengaruh langsung terhadap perakaran tanaman, air dan udara tanah. Disamping memberikan dukungan secara fisik pada tanaman, tanah merupakan sumber mineral dan air bagi tanaman. Kondisi tanah dan mineral dapat mempengaruhi pertumbuhan tanaman. Sifat-sifat fisika tanah diketahui sangat mempengaruhi pertumbuhan dan produksi tanaman karena kondisi fisik tanah menentukan penetrasi akar di dalam tanah sehingga memudahkan akar tanaman menyerap air, retensi air, drainase, aerasi, dan nutrisi tanaman, yang mempengaruhi pertumbuhan tanaman.

Pertumbuhan tanaman yang baik tidak hanya didukung oleh sifat fisik tanah saja tetapi juga sifat biologi dan kimia tanah. Sifat biologi sebagai tempat tumbuh tanaman dan tempat hidup organisme didalamnya menyediakan unsurunsur yang diperlukan oleh tanaman dan organisme lainnya. Di dalam tanah terjadi proses-proses yang 
menghasilkan sifat biologi tanah, Misalnya adanya cacing tanah akan meningkatkan unsur nitrogen, fosfor, kalium, serta kalsium dalam tanah sehingga dapat meningkatkan kesuburan tanah dan ketersediaan unsur hara bagi tanaman. Selain dari sifat fisika dan biologi yang dapat mempengaruhi pertumbuhan tanaman yaitu sifat kimia (Buckman, H dan N.C Brady 1982:34).

Sifat kimia merupakan kandungan bahan organik, unsur hara, dan $\mathrm{pH}$ tanah, bahan organik, yang dimaksud dalam penelitian ini adalah bokashi sekam padi. Kandungan bahan organik tanah mempengaruhi karakteristik tanah, pada tanah dengan kandungan bahan organik tinggi akan memberikan efek warna tanah coklat hingga hitam. Sifat kimia tanah yang lain berupa derajat keasaman atau $\mathrm{pH}$ tanah. $\mathrm{pH}$ tanah dikatakan normal dan baik untuk pertumbuhan tanaman yaitu antara 6,5 sampai dengan 7,5. Pada keadaan ini semua unsur hara pada larutan tanah dalam keadaan tersedia bagi pertumbuhan tanaman seperti unsur nitrogen, fospor dan kalium.
Setyamijaya

(1986:16)

mengatakan bahwa unsur nitrogen yang ada dalam pupuk organik mampu mempengaruhi pertumbuhan meristem apikal untuk dapat berkembang. Zubachtirodin dan Subandi (2007:28) juga mengatakan bahwa tinggi tanaman dipengaruhi oleh pemberian nitrogen yang dapat meningkatkan tinggi tanaman.

Peningkatan jumlah daun sangat dipengaruhi oleh unsur nitrogen, fosfor dan kalium selain faktor lingkungan seperti suhu dan cahaya. Hal ini juga tidak terlepas dari fungsi ketiga unsur tersebut bagi tanaman, yaitu dapat memacu pertumbuhan. Unsur nitrogen dapat memperbaiki pembelahan sel dan pembentukan bunga, unsur kalium dapat mengaktifkan enzim dan melancarkan proses penyerapan unsur hara (Harjadi, 1991:23).

Pertumbuhan tanaman dalam penelitian ini ditunjukan dengan tinggi tanaman tertinggi $15,04 \mathrm{~cm}$ dan jumlah daun yang terbanyak 5,50 helai. Tinggi tanaman dan jumlah daun yang bertambah sebagai bukti bahwa terjadi proses perpanjangan dan penambahan jumlah sel di dalam 
Pemberian Bokashi Sekam Padi Terhadap Pertumbuhan Dan Hasil Sawi Ladang (Nasturtium montanum Wall.)

tubuh tanaman. Notohadiprawiro (1984:3) mengemukakan bahwa pemberian bahan organik mampu memperbaiki sifat fisik, kimia serta biologi tanah dengan cara melepaskan ion hara dari unsur yang mengikat mineral tanah. Lepasnya ikataan hara dari partikel tanah menyebabkan unsur hara menjadi tersedia bagi tanaman sehingga unsur-unsur hara tersebut berperan penting dalam memacu pembentukan sel, perpanjangan maupun jumlah sel baru.

Pertumbuhan sawi ladang menyebabkan adanya peningkatan tinggi dan jumlah daun, yang diikuti juga oleh peningkatan berat segar tanaman. Berat segar tanaman tertinggi 50 gram yang dicapai pada taraf perlakuan $3 \mathrm{~kg}$ bokashi sekam padi per petak. Selain berat segar tanaman, tinggi tanaman dan jumlah daun juga tertinggi pada taraf perlakuan ini. Taraf perlakuan $3 \mathrm{~kg}$ bokashi sekam padi per petak bukan merupakan taraf perlakuan yang tertinggi. Hal ini diduga pelepasan unsur hara dari bokashi sekam padi menjadi unsur hara yang tersedia bagi tanaman sawi ladang berlangsung lambat. Menurut Tola dkk. (2007:1-8) bahwa pemberian pupuk organik pada dosis yang tinggi tidak disertai dengan pertumbuhan dan hasil tanaman karena sifatnya dalam menyediakan unsur hara bagi tanaman bersifat sangat lambat. Gardner, dkk (2001:138) menjelaskan bahwa penambahan hara ke dalam tanah pada kondisi status hara dalam tanah pada taraf berkecukupan tidak akan diikuti oleh peningkatan pertumbuhan dan hasil tanaman.

\section{KESIMPULAN DAN SARAN}

\section{Kesimpulan}

Bokashi sekam padi berpengaruh sangat nyata terhadap pertumbuhan dan hasil tanaman sawi ladang pada tanah PMK. Dosis $3 \mathrm{~kg}$ bokashi sekam padi memberikan pertumbuhan dan hasil yang terbaik tanaman sawi ladang pada tanah PMK, dengan tinggi tanaman 15,04 $\mathrm{cm}$, jumlah daun 5,50 helai dan berat segar tanaman 50 gram.

\section{Saran}

Bokashi sekam padi dapat diberikan pada tanah PMK untuk 
Pemberian Bokashi Sekam Padi Terhadap Pertumbuhan Dan

Hasil Sawi Ladang (Nasturtium montanum Wall.)

meningkatkan pertumbuhan dan hasil

tanaman sawi ladang.

\section{DAFTAR PUSTAKA}

Buckman, H dan N.C Brady. 1982. Kesuburan Tanah dan Pemupukan Tanah Pertanian. Bandung: Pustaka Buana.

Cahyono, B. 2015. Teknik dan Strategi Budi Daya Sawi Hijau. Yogyakarta: Yayasan Pustaka Nusatama.

Gardner, F. P., Pearce, R. B. and Mitchell, R. L. 1991. Fisiologi Tanaman Budidaya (Diterjemahkan oleh: Herawati Susilo). Jakarta: Universitas Indonesia Press.

Harjadi. 1991. Pengantar agronomi.Jakarta: PT Gramedia Pustaka Utama.

Kesumaningwati, R. 2014. Pemanfaatan Sisa Panen dalam Bentuk Bokashi Sekam terhadap Peningkatan beberapa Sifat Kimia ( $\mathrm{HH}, \mathrm{C}$ organik, N, P, dan K) Tanah Sawah. Prosiding Seminar Nasional Kimia. Fakultas
Pertanian Universitas

Mulawarman. Samarinda.

Nurhadiah. 2016. Pengaruh bokashi sekam padi terhadap hasil tanaman jagung manis (Zea mays, L Sacharata) pada Tanah Ultisol. Jurnal Piper No. 23 Vol. 12. Hal.147-154.

Notohadiprawiro, T. 1984. Pengelolaan Kesuburan Tanah dan Peningkatan Efisiensi Pemupukan. Jurusan Tanah. Fakultas Pertanian. Universitas Gajah Mada.

Setyamijaya.1986. Pupuk dan Pemupukan. Jakarta: CV Simplex.

Tola., F. Hamzah., Dahlan., Kaharudin. 2007. Pengaruh Penggunaan Dosis Pupuk Bokashi Kotoran Sapi Terhadap Pertumbuhan dan Produksi Tanaman Jagung. Jurnal Agrisistem. Vol. 3.No. 1.Juni 2007.

Yulianingsih, R. 2018. Pengaruh Bokashi Sekam Padi terhadap Pertumbuhan dan Hasil Kangkung Darat (Ipomoeae reptans Poir). Jurnal Piper No. 27 Vol. 14. Hal.377-384. 